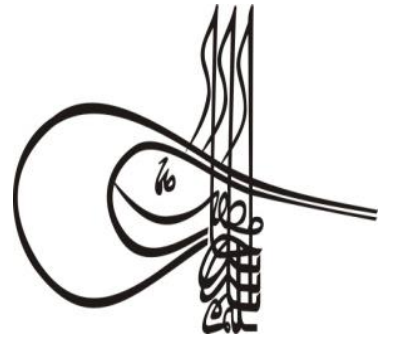

\section{Economics, Finance, Politics}

Volume 14 Issue 3, 2019, p. 975-994

DOI: 10.29228/TurkishStudies.36918

ISSN: 2667-5625

Skopje/MACEDONIA-Ankara/TURKEY

Research Article / Araștırma Makalesi

Article Info/Makale Bilgisi

Received/Geliș: 30.09 .2019

VAccepted/Kabul: 30.09 .2019

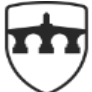

INTERNATIONAL BALKAN UNIVERSITY

EXCELLENCE FOR THE FUTUR IBU.EDU.MK

Report Dates/Rapor Tarihleri: Referee 1 (16.09.2019)-Referee 2 (28.09.2019)

This article was checked by turnitin.

\title{
YEREL YÖNETIMLERDE EVSEL KATI ATIK YÖNETIMİ VE GELECEĞİ HAKKINDA BİR DEĞERLENDİRME
}

\author{
Didem SAYGIN* - Orhan Veli ALICI**
}

\begin{abstract}
Öz
2010 yılında yürürlüğe koyulan bir yönetmelik ile evsel katı atıkların toplanması ve bertaraf edilmesine dair usul ve esaslar belirlenmiştir. Anılan sürecin sahipleri olarak da büyükşehir belediyeleri, diğer belediyeler ve belediye birlikleri sayılmıștır. Bu hizmet kapsamında da toplam sistem maliyeti ile kirleten öder ilkesi gereği tarifelerin belirlenmesi yoluna gidilmiş, ilgili bakanlı tarafından gerekli dokumanlar hazırlanarak rehberlik faaliyetinde bulunulmusstur. Ancak 2010 yılında yürürlüğe giren bu yönetmeliğin hükümlerinin evsel katı atık idarelerince bir yıl içerisinde sağlanması hüküm altına alınmışken neredeyse her yıl yapılan değişiklikle bu süreç 31/12/2020 tarihine dek uzatılmıştır. Hâlihazırda çevrenin korunması ve buna bağlı olarak herkesin dengeli ve sağlıklı bir çevrede yaşaması amacına hizmet eden bu düzenleme büyük oranda uygulama alanı bulamamıştır. Söz konusu mevzuata uyum sağlayanlar ile bu yönde gerekli adımları atmaya başlayan belediyelerde ise gerek mevzuatın bazı hususlara değinmemesi gerekse de sistemin oldukça karmaşık olması nedeniyle önemli sorunların yaşandığı gözlemlenmiștir. Bu makalede de anılan sürecin tarihsel gelişimi, uygulanmasında karşılaşılan sorunlar, çözüm önerileri ile özellikle çevreye dair bu tür vergi ve ücretlerin tek tipleştirilmesinin önemine değinilecektir. Ayrıca evsel katı atıkların vergilendirilmesi ile ilgili olarak Avrupa Birliği ve gelişmiş ülkelerdeki uygulamalara da yer verilecektir. Özellikle 1970'li yıllarda Avrupa Birliği gündemine gelen katı atık yönetimi çeşitli yasal düzenlemeler ve uygulamalarla üye ülkelerde geliştirilmiştir.
\end{abstract}

Dr. Öğr. Üyesi Çanakkale Onsekiz Mart Üniversitesi, E-posta: didemsaygin@ gmail.com

Doç. Dr. Tarsus Üniversitesi, E-posta: orhanvelialici@tarsus.edu.tr 
Anahtar Kelimeler: Yerel Yönetimler, Evsel Katı Atık, Kirleten Öder, Çevre Temizlik Vergisi, Avrupa Birliği Evsel Katı Atık Vergileri.

\title{
AN ASSESSMENT ON MANAGEMENT AND FUTURE OF DOMESTIC SOLID WASTE IN LOCAL GOVERNMENTS
}

\begin{abstract}
A regulation was adopted in 2010 to determine the procedures and principles regarding the collection and disposal of domestic solid waste. Metropolitan municipalities, other municipalities and municipal associations were put in charge of the a forementioned process. Withinthescope of this service, thetariffsweredetermined in accordance with the total system cost and polluter pays principle. Counselling activities were carried out by the relevant ministry by preparing the necessary documents. The provisions of this regulation, which came into force in 2010, were supposed to be implemented within a year by the domestic solid waste administrations. However, this process has been extended until 31/12/2020 with amendments made almost everyyear. This regulation, which currently serves the purpose of protecting the environment and enabling everyone to live in a balanced and healthy environment, has failed to find a scope of application to a great extent. It is observed that the municipalities, which have started to take the necessary steps in this direction, and those who are in compliance with the a forementioned legislation have experienced significant problems due to the fact that the legislation does not address certain issues and that the system is quite complex. This article will discuss the historical development of the a forementioned process, the problems with it simplementation, the solution proposals and, in particular, the importance of the standardization of such taxes and fees regarding the environment. In addition, practices in the European Union and developed countries will be included in the taxation of domestic solid wastes. Especially in the 1970s, solid waste management, which came to the agenda of the European Union, was developed in member countries with various legal regulations and practices.
\end{abstract}

\section{STRUCTURED ABSTRACT}

The industrialization and urbanization process experienced by the developed and developing countries in the world has started to cause damages that are difficult to recover on the environment.Thus, both environmental pollution and the process of consuming natural resources have been accelerated.Technological advances increase the life welfare of people, but these advances have made it impossible for them to live in a healthy and balanced environment.For this reason, regulations have been made especially in developed countries to protect the environment.These increasing initiatives and awareness as of the 1970s have been statedin the Article 56 of the 1982 Constitution in Turkey.Accordingly, in addition to the fact that everyone living in a healthy and balanced environment it has become the responsibility of

Turkish Studies - Economics, Finance, Politics

Volume 14 Issue 3, 2019 
the state and citizens to develop the environment, protect environmental health and prevent environmental pollution.The Environmental Law, which was enacted in 1983, included important regulations.For instance, the duty of collection and disposal of domestic solid wastes was given to the municipalities andit was decided that the costs to be met by the beneficiaries.Thus, the reduction of waste consumption and the protection of the environment were supported by 'the polluter pays' principle.With the laws numbered 5216 and 5393, the protection of the environment and collection and disposal of solid wastes in the metropolitan and other municipalities are also included in special laws.A regulation that entered into force in 2010 set forth the principles and procedures for the collection and disposal of domestic solid wastes.As the owners of this process, metropolitan municipalities, other municipalities and unions of municipalities have been counted.Within the scope of this service, tariffs have been determined in accordance with the total system cost and 'polluter pays' principle, necessary documents have been prepared by the relevant ministry and guidance has been provided.Although the provisions of this regulation, which entered into force in 2010, were to be implemented by domestic solid waste administrations within one year, this process was extended until $31 / 12 / 2020$ with the amendments made almost every year.For this reason, this regulation, currently serving the purpose of protecting the environment and consequently ensuring that everyone lives in a balanced and healthy environment, has not been implemented to a large extent.It has been observed that significant problems are experienced in the ones who comply with the said legislation and in the municipalities that have started to take the necessary steps in this direction due to the fact that the legislation does not address some issues and the system is quite complex. When the regulation currently applied by very few administrations is examined, it is seen that this regulation in 2010 does not have the nature to solve the problems especially among the administrations within the scope of metropolitan municipalities, it does not contain provisions at the essential points, it is quite detailed at the cost calculation point and it is difficult to be implemented by the municipalities due to structural and administrative problems.In this article, the historical development of this process, the problems encountered in its implementation, solution proposals and the importance of uniformization of such taxes and fees related to the environment have been addressed.In addition, practices in taxation of domestic solid wastes in the European Union and developed countries are also included. As a result, the following points were considered to be significant.In order to implement and maintain the domestic solid waste management system without any problems, firstly, it is necessary to adjust the related regulation in detail and to provide solutions that will solve the problems encountered in practice.In this context, it is useful to clearly define the aims of domestic solid waste collection and disposal system with the awareness of environmental protection and especially the definition of domestic solid waste and the nature of these wastes.In addition, simplifying the processes such as the calculation of the cost, and designing so that it can be implemented by considering the personnel structure of the municipalities will benefit the operation of the system. The fact that domestic solid waste administrations consider the water subscription agreement to be sufficient instead of the obligatory contract will eliminate the uncertainty encountered in 
practice.In determining the domestic solid waste fee, it is regulated that the fee will be determined with respect to the "variable tariff" or "fixed tariff".However, in accordance with the 'polluter pays' principle, it is stated in the same article that each waste producer should take into account the cost of the services received and that everyone should pay the same amount of household solid waste as they do.Therefore, according to the current legislation, an objective amount of pollution and price cannot be not determined.In this respect, it will be more rational to determine the domestic solid waste fee by associating the fixed fee per subscriber covered by the total system cost with the water consumption. On the other hand, it would be beneficial for metropolitan municipalities to prevent that different cost items and transportation and collection expenses are calculated by the district municipalities within the scope of coordination task and to ensure that common cost items are taken as basis. On the other hand, it is necessary to clarify the implementation of invoicing of domestic solid waste fee over water bills.As a matter of fact, there is a legal gap regarding the administration of the uncollectible domestic solid waste fee. Based on these drawbacks and problems, it is important to act with a holistic taxation practice based on the 'polluter pays' principle as in the European Union and developed countries.Moreover, it would be beneficial to have a single administration as the addressee of the taxes including domestic solid waste as well as other pollution elements.Thus, it is obvious that there will be a simplification in terms of citizens and administrations.Efficient implementation of the domestic solid waste system will increase recycling and reduce the amount of waste and this will increase environmental awareness.

Keywords: LocalGovernments, Domestic Solid Waste, Polluter Pays, Environmental Cleaning Tax, EU Domestic Solid WasteTaxes.

\section{Giriş}

Son yüzyılda yaşanan hızlı sanayileșme ve buna bağlı olarak artan kentleşme ile beraber teknolojik gelişmeler ve tıptaki ilerleme neticesinde hızlı bir nüfus artışı yaşanmıştır. Özellikle doğal kaynakların sanayileşme ve teknolojik gelişme ile beraber hızla tüketilmesi ve artan nüfusun bu yeniliklerle beraber hayat standartlarının artması doğrudan doğruya çevrenin kirletilmesi ile beraber kişi başına düşen katı atık miktarını da giderek arttırmıştır (Saltabaş, vd. 2011: 109-110). Yaşanan bu gelişim süreci bir yandan kentsel hayatın kalitesini ve insanların refahını artırırken diğer taraftan çevrenin kirletilmesine ve atık miktarının da artmasına sebebiyet vermiştir. Buna bağlı olarak da çevrenin korunması ve insanların daha sağlıklı bir çevrede yaşamasını temin edici adımların uluslararası alanda ve ulusal düzeyde atılması gerekmiştir.

1982 Anayasasının yürürlüğe girmesi ve içeriğinde çevrenin korunması ile beraber herkesin sağlıklı ve dengeli bir çevrede yaşama hakkının devlet güvencesi altına alınması ile beraber çevrenin korunması ve geliştirilmesi noktasında düzenlemeler yapılmaya başlanıldı̆̆ 1 görülmüştür. Özellikle çevrenin korunması ve geliştirilmesi noktasında uluslararası düzeyde yaşanan gelişmeler ve çeşitli hukuksal metinler ile raporlar Türkiye'de de yankı bulmuş, bu yönde gerek idari teşkilatın düzenlenmesi gerekse de çevrenin bir kanun ile korunması ve geliştirilmesi amaçlanmıştır. Bu noktada 11/8/1983 tarih ve 18132 sayılı Resmi Gazete'de 2872 sayılı Çevre Kanunu yayımlanmış, söz konusu Kanuna göre "bütün canlıların ortak varllğı olan çevrenin, sürdürülebilir çevre ve sürdürülebilir kalkınma ilkeleri doğrultusunda korunması" amaçlanmıştır. Kirletme yasağı ile beraber kirleten öder ilkesine dayanan bu düzenleme sonrasında bilhassa 2004 yılı ile beraber yerel yönetimlerin 
mevzuatının yenilenmesi sürecinde çevrenin korunması ile katı atık hizmetinin yerine getirilmesi yönünde önemli görevler de belediyelere verilmiştir.

Gerek özel mevzuat gerekse de Çevre Kanununa göre katı atık ve evsel katı atık hizmetlerini ifa edecek olan belediyelerin anılan konularda görevlerini yerine getirebilmeleri adına Çevre ve Orman Bakanlığınca gerekli mevzuat ve rehber hazırlama süreçleri de nihayete erdirilmiş, evsel katı atık hizmetinin maliyetinin belirlenmesi ve ilgililere yüklenmesi özelinde 27/10/2010 tarihli ve 27742 sayılı Resmi Gazetede Atıksu Altyapı Ve Evsel Katı Atık Bertaraf Tesisleri Tarifelerinin Belirlenmesinde Uyulacak Usul Ve Esaslara İlişkin Yönetmelik yayımlanarak yürürlüğe konulmuştur. Söz konusu yönetmelikle çevrenin korunmasını teminen evsel katı atıkların toplanması ve bertarafı ile bunun karşılığında ilgililerden belirlenecek tarife üzerinden bir ücret alınmasına dair usul ve esaslar belirlenmiş, sistemin kurularak yönetmeliğe uyumun sağlanabilmesi için de bir yıl süre tanınmıştır. Ancak süreç içerisinde anılan yönetmelikte, altı farklı "Değişiklik Yapılmasına Dair Yönetmelik" ile bu süre birer yıl uzatılmış ve son olarak da 31/12/2020 tarihi uyumun sağlanması adına nihai süre olarak evsel katı atık idarelerine verilmiştir. Bu süre zarfınca söz konusu yönetmeliğe uyumun az sayıda belediye tarafından sağlanarak abonelerden evsel katı atık ücreti tahsil ettikleri, sayısı azımsanmayacak kadar çok olan diğer idarelerin ise yönetmeliğin "Uyum süreci" başlıklı Geçici Madde 1'de yer alan " 26/10/2011 tarihi itibarıla bu Yönetmeliğe, tarife belirleme, abonelik, sözleşme, teknik alt yapı eksiklikleri ile kendi aralarında maliyet ve bölüşüm hesabı yapmayanlar da dahil olmak üzere, uyum sağlayamamış olan atıksu altyapı yönetimleri ve evsel katı atık idareleri, 31/12/2020 tarihine kadar bu Yönetmeliğe uyum sağlamakla yükümlüdürler" hükmüne istinaden herhangi bir faaliyet yürütmedikleri görülmüştür.

Gelinen aşama itibariyle yönetmeliğe uyumun sağlanamaması nedeniyle, bu yöndeki sürecin sürekli olarak ileriye bırakılması, çevreye dair çeşitli vergilerin yanı sıra vatandaşlarca anlaşılması güç mahiyetteki bu ücretin tahsili noktasında gerek siyasi gerekse de yönetimsel anlamda çeşitli sorunların yaşandığı görülmektedir. Bu makalede de evsel katı atık yönetim sürecinin zaman içerisindeki uygulanamama sorunu ile mevzuattan kaynaklanan ve idareler arasındaki ilişkileri etkileyen belirsizliklerin neler olduğuna değinilecek, çözüm önerilerinde bulunularak çeşitli ücret ve vergilerin yönetimsel kolaylık sağlaması adına birleştirilip birleştirilemeyeceği hususları irdelenecektir.

\section{Yerel Yönetimler Mevzuatında Çevrenin Korunması}

1961 Anayasası herkesin sağlıklı ve dengeli bir çevrede yaşamasını teminen çevrenin kirlenmesini önlemek noktasında bir düzenlemeye gitmemiştir. Sadece çevrenin korunması ile ilgili olarak dolaylı da olsa "Tarımın ve Çiftçinin Korunması" ve "Ormanların ve Orman Köylüsünün Korunması, Ormanların Geliştirilmesi” maddelerine yer vermiştir. 1982 Anayasasının 56'ncı maddesinde ise "Herkes, sağlıklı ve dengeli bir çevrede yaşama hakkına sahiptir. Çevreyi geliştirmek, çevre sağlığını korumak ve çevre kirlenmesini önlemek Devletin ve vatandaşların ödevidir." hükmüne yer verilerek, en üst norm düzeyinde devlet güvencesi taşıyacak şekilde herkesin sağlıklı ve dengeli bir çevrede yaşama hakkı olduğu vurgulanmıştır.

Yerel Yönetimlerin asli mevzuatına bakıldığında 5393 sayılı Belediye Kanununun "Belediyenin görev ve sorumlulukları" başlıklı 14 üncü maddesinde yer alan ve belediyenin zorunlu olan görevlerini sayarken "çevre ve çevre sağllğı, temizlik ve katı atık (...) hizmetlerini yapar veya yaptırır" düzenlemesine yer verilmiştir. 15 inci maddesinde de katı atıkların toplanması, taşınması, ayrıştırılması, geri kazanımı, ortadan kaldırılması ve depolanması ile ilgili bütün hizmetleri yapmak ve yaptırmak yetki ve imtiyazı belediyelere verilmiştir. 76 ncı maddesinde ise Kent Konseylerine "çevreye duyarlılık" ilkesinin hayata geçirilmesi noktasında bir görev verilmiştir.

5216 sayılı Büyükşehir Belediyesi Kanununun büyükșehir belediyelerinin görev ve sorumluluklarını düzenleyen 7 nci maddesinde "Sürdürülebilir kalkınma ilkesine uygun olarak çevrenin, tarım alanlarının ve su havzalarının korunmasını sağlamak" ve "inşaat malzemeleri, hurda

Turkish Studies - Economics, Finance, Politics

Volume 14 Issue 3, 2019 
depolama alanları ve satış yerlerini, hafriyat toprağı, moloz, kum ve çakıl depolama alanlarını, odun ve kömür satış ve depolama sahalarını belirlemek, bunların taşınmasında çevre kirliliğine meydan vermeyecek tedbirler almak" görevlerine yer verilmiş, aynı kanun belediye meclisinde kurulacak komisyonlar arasında çevre ve sağlık komisyonunun teşekkül ettirilmesini zorunlu kılmıştır.

Genel mevzuat anlamında da yereli de ilgilendirecek mahiyette önemli düzenlemeler içeren 9/8/1983 tarihli ve 2872 sayılı Çevre Kanunu hala yürürlükte olup, mezkur kanun çevrenin korunmasına, iyileştirilmesine ve kirliliğinin önlenmesine ilişkin genel ilkeler belirlemiş, çevrenin korunması için önlemler ve yasaklar belirlemiştir. Söz konusu Kanunun 11 inci maddesinde ise "Büyükş̧ehir belediyeleri ve belediyeler evsel katı atık bertaraf tesislerini kurmak, kurdurmak, işletmek veya işlettirmekle yükümlüdürler. Bu hizmetten yararlanan ve/veya yararlanacaklar, sorumlu yönetimlerin yapacağı yatırım, işletme, bakım, onarım ve sslah harcamalarına katılmakla yükümlüdür. $\mathrm{Bu}$ hizmetten yararlananlardan, belediye meclisince belirlenecek tarifeye göre kat1 atık toplama, taşıma ve bertaraf ücreti alınır. Bu fikra uyarınca tahsil edilen ücretler, katı atıkla ilgili hizmetler dışında kullanılamaz." denilerek evsel katı atık konusunda da belediyeler görevli ve sorumlu kılınmıştır. Anılan maddeye dayanılarak da Atıksu Altyapı ve Evsel Katı Atık Bertaraf Tesisleri Tarifelerinin Belirlenmesinde Uyulacak Usul ve Esaslara İlişkin Yönetmelik yayımlanarak yürürlüğe konulmuş, usul ve esaslar belirlenerek söz konusu görevin, başka bir deyişle evsel katı atık idarelerinin hangi idareler olacağı hususu açıklığa kavuşturulmuştur.

Ancak yerel yönetimlerin bu yöndeki karar ve politikaları ile uygulamaları her ne kadar yukarıda zikredilen mevzuata dayansa da, vesayet makamı sıfatı ile Merkezi İdarenin bu sürece dair ülke genelinde uygulamaların eşgüdüm dâhilinde yürütülebilmesi için standartlar geliştirerek strateji ve politika belirleme görevi bulunmaktadır. Hâlihazırda 10 Temmuz 2018 tarihinde yürürlüğe giren 1 Nolu Cumhurbaşkanı Kararnamesi ile teşkilatlanan Çevre ve Şehircilik Bakanlığına bağlı Çevre Yönetimi Genel Müdürlüğünün görevlerini düzenleyen 103' üncü maddesine bakıldığında Bakanlığın genel olarak "atık" konusunda var olan görevleri aşağıda gösterilmiştir.

- Çevre kirliliğinin önlenmesi ve kontrolü ile ilgili mevzuatı hazırlamak, standart geliştirmek, ölçüm, tespit ve kalite ölçütlerini belirlemek; alıcı ortam özelliklerine göre çevre kirliliği yönünden görüş vermek,

- Serbest bölgeler dâhil olmak üzere, ülke genelinde çevreye olumsuz etkileri olan atık ve kimyasallar ile hava kirliliği, gürültü ve titreşim ile ilgili ölçütleri belirlemek,

- Etkili bir çevre yönetimi gerçekleştirmek, atık ve kimyasalların çevre ile uyumunu sağlamak üzere gerekli ekonomik araçları belirlemek ve bu konuda standartlar geliştirmek,

- Atık ve kimyasalların yönetimine ilişkin hedef, politika ve ölçütlerin belirlenmesine ilişkin çalışmaları yapmak,

- Atıkların kaynağında en aza indirilmesi, sınıflara ayrılması, toplanması, taşınması, geçici depolanmas1, geri kazanılmas1, bertaraf edilmesi, yeniden kullanılmas1, arıt1lması, enerjiye dönüştürülmesi ve nihai depolanması konularında politika ve stratejilerin belirlemesi amacıyla çalışmalar yapmak,

- İlgili kurum ve kuruluşlarla işbirliği içinde atıkların taşınması ile tehlikeli atıkların taşınma lisanslarına ilişkin esasları belirlemek, uygulanmasını sağlamak, izlemek, atık ve kimyasallarla kirlenmiş alanların mevcut kirlilik durumlarını tespit etmek, çevre ve insan sağlığına yönelik risklere ve kirlenmiş alanların iyileştirilmesine ilişkin çalışmaları yapmak ve yaptırmak.

Görüleceği üzere Çevre ve Şehircilik Bakanlığının genel olarak çevrenin korunması, özel olarak da atık yönetimi konusunda hedef, politika ve ölçütleri belirleme ile bunların ilgili kurum ve kuruluşlarca uygulanmasını izlemek görevi bulunmaktadır. Bu dayanaklardan hareketle Çevre ve 
Orman Bakanlığı zamanında çıkarılan evsel katı atık ile ilgili mevzuat ve dokümanların geliştirilmesi ve uygulamada yaşanan sorunların bu suretle giderilmesi önem taşımaktadır.

$\mathrm{Bu}$ çerçevede merkezi idarenin eşgüdümü sağlayıcı, stratejileri ve standartları belirleyici bir fonksiyonu varken yerel yönetimlerin alınan bu karar ve politikaları bizzat uygulama sorumluluğu bulunmaktadır. Başka bir deyişle yerel yönetimlerin evsel katı atıkların toplanmasından taşınmasına, bertarafından geri dönüşüme tutulmasına dek esaslı ve mali açıdan külfetli görevleri bulunmaktadır. Söz konusu süreçte atıkların değerlendirilememesi halinde ise geri dönüşümü mümkün olan atıkların yaratacağı ekonomik değerler ise kaybolacaktır (Yılmaz ve Bozkurt, 2010: 12). Bu nedenle evsel katı atık yönetiminin mevzuata uygun bir şekilde yerine getirilmesi geri dönüşümü sağlamakla birlikte kirleten öder ilkesi gereği atık oluşumunu azaltacaktır. Aşağıda evsel katı atık yönetimine dair bu bilgiler ayrıntılı olarak irdelenecektir.

\section{Evsel Katı Atık Yönetimi}

Çevre Kanunu'na göre Katı Atık, “Üreticisi tarafından atılmak istenen ve toplumun huzuru ile özellikle çevrenin korunması bakımından, düzenli bir şekilde bertaraf edilmesi gereken katı atık maddeler" şeklinde tanımlanırken Evsel Katı Atık ise "tehlikeli ve zararlı atık kapsamına girmeyen konut, sanayi, işyeri, piknik alanları gibi yerlerden gelen katı atıklar" olarak açıklanmıştır. 14/03/1991 tarihli ve 20814 sayılı Resmi Gazete yayımlanarak yürürlüğe giren Katı Atıkların Kontrolü Yönetmeliğinde ise "Evsel katı atık (çöp): Konutlardan atılan, tehlikeli ve zararlı katı atık kavramına girmeyen, bahçe, park ve piknik alanları gibi yerlerden gelen katı atıklar" şeklinde tanımlanmıştır.

Daha önce de değinildiği gibi 11 inci maddede ise büyükşehir belediyeleri ile diğer belediyelerinin evsel katı atık bertaraf tesisleri kur(dur)acağı, işlet(tir)eceği bir zorunluluk haline getirilmiştir. Söz konusu hizmetten yararlananların ise belediye meclisi tarafından belirlenecek toplama, taşıma ve bertaraf ücreti ödemek suretiyle bu yönde yapılacak olan harcamalara katılacağı, tahsil edilen ücretin ise sadece bu amaç dâhilinde kullanılacağı hüküm altına alınmıştır.

Çevre Kanunun gerek 11 inci maddesi gerekse de genel anlamda atıkların kontrolü ve yönetimi ile ilgili olarak 14/3/1991 tarihli ve 20814 sayılı Resmî Gazete 'de yayımlanan Katı Atıkların Kontrolü Yönetmeliği, 14/3/2005 tarihli ve 25755 sayılı Resmî Gazete'de yayımlanan Tehlikeli Atıkların Kontrolü Yönetmeliği ve 5/7/2008 tarihli ve 26927 sayılı Resmî Gazete'de yayımlanan Atık Yönetimi Genel Esaslarına İlişkin Yönetmelik yürürlüğe konulmuştur. Akabinde de kirleten öder ilkesinin atıkların azaltılması ve kontrol altına alınması noktasında bir etki yaratması maksadıyla Atıksu Altyapı ve Evsel Katı Atık Bertaraf Tesisleri Tarifelerinin Belirlenmesinde Uyulacak Usul ve Esaslara İlişkin Yönetmelik yürürlüğe konulmuştur. Böylece evsel katı atıkların tarifelerinin belirlenmesi ve bu yönetmeliğe uyum sağlanması süreci devam ederken yukarıda zikredilen üç farklı yönetmeliği mülga kılan Atık Yönetimi Yönetmeliği 02/04/2015 tarih ve 29314 sayılı Resmi Gazete'de yayımlanarak yürürlüğe girmiştir. Bu yönetmelikle de;

a) Atıkların oluşumundan bertarafına kadar çevre ve insan sağlığına zarar vermeden atık yönetiminin sağlanmas1,

b) Atık oluşumunun azaltılması, atıkların yeniden kullanımı, geri dönüşümü, geri kazanımı gibi yollar ile doğal kaynak kullanımının azaltılması ve atık yönetiminin sağlanması,

c) Çevre ve insan sağlığı açısından belirli ölçütlere, temel şart ve özelliklere sahip, bu Yönetmeliğin kapsamındaki ürünlerin üretimi ile piyasa gözetimi ve denetimi,

amaçlanmış, gerekli usul ve esaslar belirlenerek temel ilkeler açiklığa kavuşturulmuştur.

Böylece mezkûr yönetmeliğe göre; atığın oluşumunun önlenmesi, kaynağında azaltılması, yeniden kullanılması, özelliğine ve türüne göre ayrılması, biriktirilmesi, toplanması, geçici olarak depolanması, taşınması, geri dönüşüme tabi tutulması, enerji olarak geri kazanılması, bertarafi, 
akabinde izlenmesi, kontrolü ve denetimi faaliyetleri hüküm altına alınmıştır. Anılan atık yönetim sisteminin tesis edilerek işletilmesi ve idamesi ile beraber oluşan maliyetin kirleten öder ilkesi gereğince atık üreticilerine yüklenmesi gerekmiş, hala yürürlükte olan Atıksu Altyapı ve Evsel Katı Atık Bertaraf Tesisleri Tarifelerinin Belirlenmesinde Uyulacak Usul ve Esaslara İlişkin Yönetmelik'e istinaden bu sürecin işletilmesi gerekmiştir.

Söz konusu yönetmelik ise "evsel katı atık" tanımı yapmaksızın evsel katı atık bertaraf tesisleri tarifesinin belirlenmesine dair usul ve esaslar belirlemiştir. Bu yönetmeliğe göre evsel katı atık idarelerinin büyükşehir belediyeleri, diğer belediyeler ve belediye birliklerinin olacağı, bu idarelerin ise; evsel katı atık hizmetini vermek veya verdirmek, evsel katı atık hizmetlerine ilişkin tarifeleri belirlemek ve evsel katı atık ücretini toplamak şeklinde görevlerinin olacağı belirtilmiştir.

Bahsi geçen hizmetin sunulabilmesi için evsel katı atık idarelerinin hizmetten yararlanacak olan abonelerle bir "Hizmet Sözleşmesi” imza altına alması konusunda yükümlü kılınmıştır. Evsel katı atık sisteminin maliyetinin bulunmasında tam maliyet ve kirleten öder ilkesi esas alınmakta olup, "toplama", "taşıma", "aktarma", "geri kazanım", "bertaraf" ve "satış" bileşenleri sonucunda oluşan maliyetin tespiti akabinde Evsel Katı Atık Tarifelerinin Belirlenmesine Yönelik Kılavuza göre abonelerden alınacak ücret, iki farklı şekilde ve abonenin aldığı hizmetin maliyetini geçmemek üzere belirlenmektedir. $\mathrm{Bu}$ hesaplamada varlıkların amortismanı da dikkate alınmakta, tahsil edilen ücretlerin evsel katı atık hizmetlerinde kullanılmasını sağlayacak tam maliyet muhasebe sistemi kurmaları da zorunlu tutulmaktadır. Görüleceği üzere bu aşamaya kadar evsel katı atık hizmetinin verilmesinden öte bu hizmetin maliyetinin belirlenmesi ve yararlanıcılarına ücret şeklinde pay edilmesinin oldukça karmaşık ve zor bir muhteviyat içerdiği anlaşılmaktadır.

Nihai olarak yukarıda zikredilen hususların yerine getirilmesi akabinde anılan ücretin tahsil edilmesi de belediyenin türüne göre değişmektedir. Her ne kadar yönetmelik evsel katı atık ücretinin hizmet karşı1lı̆ı olarak düzenli şekilde su faturaları ile beraber tahsil edileceğini hükme bağlasa da büyükşehir belediyeleri dışındaki diğer belediyelerde su hizmetinin aynı tüzel kişilik tarafından sunulması noktasında herhangi bir olumsuzluk yaşanmamaktadır. Ancak büyükşsehirlerde 2560 sayılı Kanun uyarınca kurulan Su ve Kanalizasyon İdarelerinin evsel katı atık ücretinin toplama kısmını ilçe belediyelerine, bertaraf kısmını da büyükşehir belediyesine aktarması gerekmektedir (Gündüzalp ve Güven, 2016: 9). Bu noktada faturalandırma özelinde büyükşehir belediyelerinde su ve kanalizasyon idareleri ile evsel katı atık idareleri arasında tahsilatın su faturaları üzerinden yapılması süreci öncesi ile sonrasına dair yönetmelik ve kılavuzda yeterli bir düzenleme bulunmamaktadır. Başka bir deyişle faturalandırılan bu ücretin kimin tarafından tahsil edileceği, tahsil edilememesi halinde icra sürecini hangi idarenin yürüteceği, tahsilatın gerçekleşememesi halinde hangi idarenin sorumlu olacağ gibi birçok noktada önemli belirsizlikler bulunmaktadır. Bu noktada süreçte yer alan idarelerin, dolayısıyla da Evsel Katı Atık Raporları ve tarifelerin farklılaşması ile beraber su ve kanalizasyon idarelerinin söz konusu belirsizlikler sebebiyle eşgüdümü sağlaması oldukça zor görünmektedir.

Yine büyükşehir belediyelerinde evsel katı atık ücretinin su faturaları ile beraber tahsili noktasında su ve kanalizasyon idareleri nezdinde yeni bir gelir kaleminin oluşturulduğu algısı da ortaya çıkmaktadır. Bu hususun da giderilmesi için anılan yönetmeliğin 23 üncü maddesi gereğince katı atık ücretinin mahiyeti hususunda hazırlanacak bir raporun yerel gazete ve haber alma yolları ile halka duyurulması ve halkın bilgilendirilmesi, alınan taleplere göre istemlerin değerlendirilmesi de gerekmektedir (Zengin ve Ulutaş, 2016: 35).

Halihazırda evsel katı atık yönetim süreci yukarıdaki şekilde gerçekleşmekte ise de mevzuat uyarınca 2010 y1lından sonra bir yıl içerisinde, yani 26/10/2011 tarihi itibariyle anılan sistemin tesis edilmesinden bütün idareler yükümlü kılınmıştır. Ancak aşağıdaki tabloya bakıldığında söz konusu uyum sağlama sürecinin sürekli olarak bir geçici madde ile ileri tarihlere uzatıldığı görülecektir. 
Tablo 1: Evsel Katı Atık İdarelerinin Yönetmeliğe Uyum Sağlama Sürecine Dair Erteleme Kararları

\begin{tabular}{|c|c|c|c|}
\hline \multicolumn{3}{|c|}{ Yönetmeliğin Yayımlandığı Resmî Gazete'nin } & \multirow{2}{*}{$\begin{array}{c}\text { Yönetmeliğe Uyum } \\
\text { Sağlama Tarihi }\end{array}$} \\
\hline & Tarihi & Sayısı & \\
\hline & 27.10 .2010 & 27742 & 26.10 .2011 \\
\hline \multicolumn{4}{|c|}{$\begin{array}{c}\text { Yönetmelikte Değișiklik Yapan Yönetmeliklerin Yayımlandığı } \\
\text { Resmi Gazetelerin }\end{array}$} \\
\hline & Tarihi & Sayısı & \\
\hline 1 & 15.02 .2013 & 28560 & 31.12 .2014 \\
\hline 2 & 23.12 .2014 & 29214 & 31.12 .2015 \\
\hline 3 & 30.12 .2015 & 29578 & 31.12 .2016 \\
\hline 4 & 25.01 .2017 & 29959 & 31.12 .2017 \\
\hline 5 & 25.01 .2018 & 30312 & 31.12 .2018 \\
\hline 6 & 02.02 .2019 & 30674 & 31.12 .2020 \\
\hline
\end{tabular}

Yukarıdaki tablo, esasında sürekli olarak gerçekleşen ertelemenin evsel katı atık idarelerince kanıksanmasına yol açtığı, böylece her yıl söz konusu uzatma hadisesinin yineleneceğinden hareketle anılan sistemin işler hale getirilmesi noktasında kayda değer bir gecikmeye sebebiyet verildiği değerlendirilmektedir. Aşağıda yönetmelik hükümleri çerçevesinde sistemin uygulanmasında karşılaşılan sorunlara yer verilecektir.

\section{Sistemin Uygulanmasında Yaşanan Sorunlar}

Çevre ve Orman Bakanlığı tarafından hazırlanarak yürürlüğe koyulan "Atıksu Altyapı ve Evsel Katı Atık Bertaraf Tesisleri Tarifelerinin Belirlenmesinde Uyulacak Usul ve Esaslara İlişsin Yönetmelik" ile "Evsel Katı Atık Tarifelerinin Belirlenmesine Yönelik Kılavuz" uyarınca Evsel Katı Atık Yönetim Sisteminin oluşturulması ve işletilmesi noktasında gerekli süreç başlatılmış olsa da gerek belediyelerin içerisinde bulunduğu yapısal ve yönetsel sorunlara gerekse de anılan sistemin oldukça karmaşı olması ile beraber mevzuattaki belirsizlikler sebebiyle öngörülen uyum sürecinde hedeflenen amaç gerçekleşmemiş, idareler arası koordinasyona bağlı uyuşmazlıklar yaşanmış, buna istinaden de uyum süreci sürekli olarak ertelenmiştir. Öncelikle Evsel Katı Atık konusunda yürürlükte olan Yönetmelik kapsamında tespit edilen sorunlar gerek mevzuat gerekse de evsel katı atık idarelerinin yapısal ve yönetsel sorunları esas alınarak aşağıda irdelenecektir.

\subsection{Evsel Katı Atık Yönetiminin Amacı, Kapsamı ve Yönetilmesi}

Söz konusu yönetmelik ve kılavuz incelendiğinde hizmetin amacı, çevrenin korunması noktasında ortaya çıkaracağı pozitif kazanımlar ile sorun teşkil eden ve öngörülebilecek mahiyetteki hususlara dair doyurucu mahiyette düzenleme ve bilginin olmadığ görülmüştür. Öncelikle yönetmelikte evsel katı atığın tanımı ile mahiyetinin neler olacağına değinilmemiştir. Dolayısıyla özellikle yetişmiş elemandan yoksun olan ve bu yönetmeliği uygulamakla zorunlu kılınmış olan belediyelerde bu işin benimsenmesi, çevreyi koruyacak şekilde geliştirilerek idame ettirilmesi konusunda bu önemli eksikliklerin giderilmesi gerekmektedir. Ayrıca genel anlamda evsel katı atık toplama ve bertarafı çerçevesinde oluşan maliyetin hesaplanması, amortismanı ve abonelere bu bedelin ücret şeklinde pay edilmesi sürecinin karmaşık bir mahiyet içermesi de yapısal ve yönetsel 
sorunları uhdesinde barındıran belediyeler açısından bir külfet olarak görülmektedir. Yetişmiş elaman yetersizliği ile beraber, işinde ehil olan personelin görevde yükselmesi veya başka idarelerde çalışmak üzere görevden ayrılması gibi durumlar da nazara alındığında söz konusu sürecin karmaşıklığı bu sistemin belediyelerde uygulanmasını ve idamesini zorlaştırmaktadır.

Bu noktada evsel katı atık toplama ve bertaraf sisteminin çevrenin korunması bilinci ile hizmet edeceği amaçların ve özellikle de evsel katı atık tanımı ile mahiyetinin açık bir şekilde tanımlanmasında ve açıklanmasında yarar görülmektedir. Diğer taraftan sürecin sadeleştirilmesi veya iş akışlarını da gösterecek şekilde, özellikle aşağıda değinilecek olan belirsizlikleri giderecek şekilde evsel katı atık yönetim sisteminin uygulanabilirliğini kolaylaştırıcı çözümlerin de geliştirilmesi bu aşamada önem taşımaktadır.

Evsel kat1 atık sisteminin yönetilmesine gelince, belediyelerin üst yöneticilerinin evsel katı atık üreticilerinden belirlenecek olan ücreti almakla yetkilendirilmiş belediyenin başkanı olması ve genel olarak tekrar seçilme kaygısı taşımaları nedeniyle de anılan sisteme uyum sağlanmasında önemli güçlükler yaşanmaktadır. Bu yeni ücretin tahsil edilmesi ve vatandaşlara bu hizmetin mahiyetinin açıklanması belediyeler açısından güç olduğundan süreç içerisinde anılan sistemin hayata geçirilmesi de büyük ölçüde mümkün olamamıştır. Diğer taraftan yönetmelik kapsamında evsel katı atık hizmetinin neler olduğu, atıksal açıdan bu hizmetin hangi atıkları kapsadığı gibi belirsizliklerin vatandaşlar nezdinde bu ücret ile Çevre Temizlik Vergisinin karıştırılmasına da yol açmaktadır. Başka bir deyişle çevre konusunda farklı ücret ve vergilerin alınması belediye yönetimleri ile vatandaşları karşı karşıya getirmektedir. Bu noktada bu ücret ve vergilerin birleştirilebilme amacı dâhilinde yeniden gözden geçirilmesinde fayda bulunmaktadır.

\subsection{Hizmet Sözleşmesi}

Yönetmelik uyarınca evsel katı atık idarelerinin, hizmetten yararlananlarla beraber yararlanacak olan her evsel katı atık üreticisi ile sözleşme yapması gerekmektedir. Ancak yönetmelikte sözleşmenin mahiyeti ile ilgili olarak bir açılamaya gidilmediği, sadece sözleşmede atık üreticisinin hangi hizmetlerden yararlandığı ve hangi tarife türü üzerinden ücretlendirildiğinin yer alması gerektiği belirtilmektedir. Kılavuzda ise sözleşmenin bir tip örneğine yer verilmediği gibi kapsamı hakkında da yeterli bilgi bulunmadığı görülmektedir. Bu noktada idareler arası eşgüdümün sağlanması adına bir tip sözleşmenin Çevre ve Şehircilik Bakanlığınca hazırlanmasının yararlı olacağı değerlendirilmektedir.

Sözleşmenin imzalanması yönetmelikte açıkça zorunlu kılınsa da bütün belediyelerce her evsel katı atık üreticisi ile sözleşme imzalanması da oldukça zor görünmektedir. Başka bir deyişle bir büyükşehirde, bütün katı atık üreticilerinin sözleşmeye imza atmak üzere ilgili idareye davet edilmesi hayatın olan akışı içerisinde pek mümkün gözükmemektedir. Bu noktada yine de bazı belediyelerce vatandaşların sözleşme imzalamak üzere belediyeye davet edildiği, bu davete icabetin oldukça sınırlı düzeyde kaldığı, yine bu durum üzerine de bazı belediyelerce imzaya gelmeyenlerin imza için tanınan süre sonunda sözleşmeyi imzalamış sayılacağı yönünde bir karar aldıkları, bazılarının ise su abone sözleşmesi olanların evsel katı atık aboneliği sözleşmesini yapmış sayılacağı yönünde meclis kararları aldıkları görülmüsstür. Ancak son yolu tercih edenlerin büyükşehir belediyeleri kapsamındaki belediyeler olması durumunda bu yerlerde su ve kanalizasyon hizmetinin özel amaçlı metropoliten kuruluşlar olan su ve kanalizasyon idarelerince sunulması ve sözleşmeleri de bu idarelerin yapması dikkate alındığında sorunu çözmekten çok daha karmaşık hale getirdikleri dikkat çekmektedir.

Öncelikle söz konusu yönetmelik gereğince anılan hizmet sözleşmesinin imzalanmasının zorunluluğunun yargı kararları çerçevesinde incelenmesi yararlı olacaktır. Danıştay Ondördüncü Dairesi'nin 2013/7603 Esas, 2015/1087 Karar nolu kararın açılama kısmında ""Abone" tarifinin hem su, hem atıksu, hem de katı atık hizmetlerinden yararlanan kişiyi ifade ettiği; su hizmetlerinden yararlanan abonenin atıksu üreteceğinin de tabii olduğu, suyun kullanılmasının ve atıksuyun meydana 
gelmesinin hayatın olağan akısı içinde, o yerde yaşamsal fonksiyonlar olduğunun ve bunun sonucunda katı atık üretiminin de olacağının kabulünü gerektirmektedir. Böylece su, atıksu ve katı atık hizmetlerinden faydalanan ve/veya faydalanacak gerçek veya tüzel kişilerin idareyle yapacakları abonelik sözleşmesi uyarınca, idarece atıksu ve katı atık yönetim sistemi ücreti tarifelerinin "kirleten öder" ilkesi uyarınca belirlenerek, su faturaları üzerinden tahsil edilebileceği, dolayısıyla su aboneliği sözleşmesinin olmasının yeterli olduğu sonucuna varılmıştır.” denilerek su aboneliğine bağlı olarak su faturası üzerinden katı atık bedeli istenmesine ilişkin dava konusu meclis kararında hukuka aykırılık görülmemiştir. Bu karara göre evsel katı atık ücretinin tahsil edilmesi için bir sözleşme imzalamak yerine su aboneliği sözleşmesinin yeterli olduğu kanaatine varıldığı anlaşılmıştır.

Ancak söz konusu uyuşmazlığın Manisa ili Soma ilçesinde gerçekleştiği, nitekim davaya konu edilen meclis kararının 24/10/2011 tarihinde İdare âleminde sonuç doğurduğu sirada bu ilçenin büyükşehir ilçe belediyesi olmadığı, başka bir deyişle su ve kanalizasyon hizmetini bu belediyenin sunduğu, dolayısıyla su abone sözleşmesini imzalayan idare ve evsel katı atık idaresi vasfi ile su faturası tahsil eden idarenin aynı tüzel kişilikte buluştuğu, ancak 30 Mart 2014 tarihi itibariyle 30 büyükşehir belediyesi ile 519 büyükşehir ilçe belediyesinde su ve kanalizasyon görevi 2560 sayılı Kanun uyarınca görev yapan Su ve Kanalizasyon İdarelerinde (SUKI) bulunmaktadır. Böylece il mülki sınırı uygulaması ile beraber büyükşehir sınırlarına dahil olan ilçe belediyelerinin evsel katı atık idaresi olarak su aboneliği sözleşmesi imzalama ve faturalandırma yetkisi kalmamıştır. $\mathrm{Bu}$ aşamada 6360 sayılı Kanunun uygulama alanı bulduğu büyükşsehir ve ilçe belediyelerinde mezkûr yargı kararının icra tatbikinin mümkün olamayacağı sonucu ortaya çıkmıştır. Başka bir deyişle evsel katı atık idaresi ile su abone sözleşmesi imzalayan ve su faturası basarak tahsil eden iki farklı tüzel kişilik olunması sebebiyle Atıksu Altyapı ve Katı Atık Bertaraf Tesisleri Tarifelerinin Belirlenmesinde Uyulacak Usul ve Esaslara İlişkin Yönetmeliğin 12' nci maddesine istinaden Evsel Katı Atık İdarelerinin bu sözleşmeyi imzalaması gerektiği kanaati ortaya çıkmıştır.

Hal böyle iken 2018 y1lı içerisinde bahsi geçen yönetmeliğe uyum sağlayan idarelerin tespitine gidildiğinde sadece Tekirdağ Büyükşehir Belediyesinin yukarıda zikredilen yargı kararına atıf yaparak hizmet sözleşmesinin imzalanması noktasında farklı bir argüman geliştirdiği görülmüştür. Söz konusu idare yukarıda yer verilen yargı kararı gereğince "TESKİ ile abonelik sözleşmesi yapmış olanlar (...) Yönetmeliğin 12' nci maddesinde belirtilen sözleşmeyi yapmış sayılır" şeklinde bir Büyükşehir Belediye Meclisi kararı aldığı görülmüştür. Bu noktada Büyükşehir Belediye Meclisinin SUKI'lerin Genel Kurulu olduğu ve 5216 sayılı Kanunun 27 nci maddesi uyarınca eşgüdüm sağlama görevini ifa ettiği değerlendirildiğinde yapılan idari işlemin idare âleminde sonuç doğuracak bir mahiyet taşıdığı değerlendirilmiştir.

Öte yandan yine 2018 yılı itibariyle bazı ilçe belediyelerinin de gerekli uyumu sağladıktan sonra meclis kararı aldıkları ve vatandaşları sözleşme yapmak amacıyla belediyeye davet ettikleri, tanınan sürenin sonuna dek gelmeyenlerin ise bu sözleşmeyi imzalamış kabul edileceği yönünde Meclis Kararı alarak bunu duyurdukları tespit edilmiştir.

$\mathrm{Bu}$ noktada anılan sözleşmenin imzalanması noktasında üç farklı yola tevessül edildiği görülmektedir.

1-) Büyükșehir olmayan yerlerde, belediyenin abone ile su abone sözleşmesi imzalandığından bu belediyelerce "Su abone sözleşmesi imzalayanlar evsel katı atık sözleşmesini de imzalamış sayılır" ibaresi ile Evsel Katı Atık Raporunu Meclis Kararı ile kabul etmektedir.

2-) Büyükşehir Belediyeleri ile diğer belediyelerde vatandaşların belediyeye söz konusu sözleşmeyi imzalamak üzere davet edilmekte, öngörülen süre dahilinde gelmeyenlerin bu sözleşmeyi imzalamış sayılacağı yönünde meclis kararı alarak bunu vatandaşlara uygun yöntemlerle duyurmaktadır. 
3-) Özellikle bazı Büyükşehir Belediyelerinde "Danıştay Ondördüncü Dairesi'nin 2013/7603 Esas, 2015/1087 Karar nolu kararı ile; "abone" tarifinin hem su, hem atıksu hem de katı atık hizmetlerinden yararlanan kişiyi ifade ettiği; su hizmetlerinden yararlanan abonenin atıksu üreteceğinin de tabii olduğu, suyun kullanılmasının ve atıksuyun meydana gelmesinin hayatın olağan akışı içinde, o yerde yaşamsal fonksiyonlar olduğunun ve bunun sonucunda katı atık üretiminin de olacağının kabulünü gerektirmektedir. Böylece su, atıksu ve katı atık hizmetlerinden faydalanan ve/veya faydalanacak gerçek ve tüzel kişilerin idareyle yapacakları abonelik sözleşmesi uyarınca, idarece atıksu ve katı atık yönetim sistemi ücreti tarifelerinin "kirleten öder" ilkesi uyarınca belirlenerek, su faturaları üzerinden tahsil edilebileceği, dolayısıyla su aboneliği sözleşmesinin olmasının yeterli olduğu sonucuna varılmıştır." kararı verilmiş olup, Su ve Kanalizasyon İdaresi ile abonelik sözleşmesi yapmış olanlar 27.10.2010 tarih 27742 sayılı R.G'de yayımlanan Atıksu Altyapı ve Evsel Katı Atık Bertaraf Tesisleri Tarifelerinin Belirlenmesinde Uyulacak Usul ve Esaslara İlişkin Yönetmeliğin 12 inci maddesinde belirtilen sözleşmeyi yapmış sayılır." ibaresinin yer aldığı bir Meclis Kararı alınarak bu kararı vatandaşlara duyurmaktadır.

Görüleceği üzere mevzuatın yeterince açık olmamasından kaynaklanan uygulama farklılıklarının yaşandığı açıktır. Diğer taraftan mevzuat hükümleri esas alındığında yönetmeliğin düzenlenmesi sırasında büyükşehir belediyeleri, SUKI'ler ve ilçe belediyelerinin süreç içerisindeki konumu yeterince değerlendirilmeden bu düzenlemelerin yapıldığg sonucu oraya çıkmaktadır.

\subsection{Tarife ve Ücretlendirme}

Söz konusu Yönetmeliğin 18 inci maddesine göre tam maliyet esasının dikkate alınarak evsel katı atık hizmetlerine ait ücretler belirlenirken, atık üreticisinin ürettiği atık miktarının aşağıda yer verilen kıstaslardan biri veya birkaçı kullanılarak tespit edilecektir. Bu kıstaslar şunlardır:

a) Atık ağırlı̆̆

b) Konteyner sayısı, konteyner hacmi, konteyner doluluk oranı ve atık toplama sıklığı,

c) Atık toplama aracı sayısı, araç hacmi, araç doluluk oranı ve atık toplama sıklığı,

ç) Atık üreticilerinin hanehalkı büyüklüğü, hastanelerde yatak sayısı, okullarda öğrenci sayısı gibi belirli özelliklerine göre belirlenebilecek sabit atık üretim değerleri.

Yukarıda yer verilen kıstasların genel olarak ölçülebilir olduğu, ancak atık üreticisi olan her bir abonenin tüketimini rasyonelce ölçemeyeceği öngörülmektedir. Yönetmeliğin "Evsel katı atık tarife türleri” başlıklı 20' nci maddesine bakıldığında ise tarifenin atık miktarı belirleme yöntemine göre iki farklı şekilde belirleneceği ve buna göre ücretlendirmenin yapılacağı düzenlenmiştir. Bu tarife türleri ise;

a) 18 inci maddede belirtilen yöntemlere göre hesaplanmış ve değişken ücretlerden oluşan tarife,

b) Kirleten öder ilkesi dikkate alınarak ve 18 inci maddede belirtilen yöntemlere göre idareler tarafından hesaplanmış ve üretilen atık miktarını atık üreticilerinin etkileyemediği sabit tarife.

Söz konusu tarifeler uyarınca ücretin belirleneceği açık olmakla beraber aynı maddenin ikinci fıkrasında evsel katı atık idarelerince her atık üreticisinden sadece aldıkları hizmetlerin maliyetleri dikkate alınarak tarife belirleyeceği hususuna yer verilmiştir.

$\mathrm{Bu}$ noktada anılan yetkinin nihai olarak belediye meclisi uhdesinde olduğu açık olmakla beraber büyükşehir belediyelerinde durumun farklı olduğu görülmektedir. Buna göre evsel katı atıkları toplanması ve taşınması akabinde katı atıkların bertaraf sürecine dair bütün giderlerin içinde yer aldığı maliyet unsurlarına göre belirlenecek olan ücretin, 2872 sayılı Kanunun 11/11. maddesi ile 5216 sayıl1 Kanunun 7/1-i maddesi uyarınca Büyükşehir Belediye Meclisince belirlenmesi gerekmektedir. Başka 
bir deyişle büyükşehir ilçe belediyelerinin özerk bir şekilde toplama ve taşıma giderleri üzerinden belirleyeceği ücreti bizzat uygulama veya SUKI'ye göndererek tahsil etme yetkisi bulunmamaktadır. Ancak belirlenen taşıma ve toplama giderinin yönetmelik esaslarınca ücreti ve tarifesi belirlendikten sonra kendi meclisinden alacağı kararı büyükşsehir belediye meclisine göndermesi ve bütün ilçe belediyelerinin tarifelerini eşgüdüm sağlaam görevi çerçevesinde büyükşehir belediye meclisinin kabul etmesi halinde söz konusu işlemin geçerlilik taşıyacağı, ancak nihai kararın büyükşehir belediye meclisi kararı olacağı da açıktır. Nitekim bazı büyükşehir ilçe belediyelerinin kendi uhdesinde nihayete erdirerek abonelerden evsel katı atık ücreti tahsil etme işlemi İdari yargı kararları ile iptal edilmiştir. $\mathrm{Bu}$ çerçevede evsel katı atıkları toplama ve taşıma aşamalarının da dahil olduğu katı atıkların bertaraf sürecine ilişkin giderlerin, buna bağlı olarak tarifelerin ve ücretin belirleme nihai yetkisinin büyükşehir belediye meclisinde olduğu, bu noktada büyükşehir belediyesinin eşgüdüm görevi de dikkate alındığında bertaraf dışında taşıma ve toplama giderlerinin ortak hesaplama verileri ile belirlenmesi adına büyükşsehir belediyesinin ilçe belediyeleri ile beraber bu süreci nihayete erdirmesinin daha rasyonel olacağı değerlendirilmektedir.

Bütün bu açıklamalar dikkate alındığında öncelikle atığın miktarının belirlenmesi için çeşitli kıstaslara yer verildiği, bunların yeterince ölçülebilir olmadığı, özellikle sürekli değişecek mahiyette olan hane halkı, hasta ve öğrenci sayısı gibi verilerin sağlıklı bir sonuç veremeyeceği öngörülmektedir. Diğer taraftan bu ölçülebilir olmayan miktarlar özelinde de tarife belirleneceği, bu uygulamanın esas alınmaması halinde de toplam sistem maliyetinden ÇTV gibi bedeller düşüldükten sonra sabit bir tarifenin belirlenebileceği anlaşılmaktadır. Bu bilgiler nazara alındığında kirleten öder ilkesinin evsel katı atık üreticisine rasyonel bir şekilde yansıtılmasının oldukça güç olduğu değerlendirilmektedir. Ancak yukarıdaki yöntemlerle beraber genel mahiyette bir sabit tarifenin bulunarak, her bir aboneye bölünmesi neticesinde elde edilen atık maliyetinin, bir de evsel katı atık üreticisi konumunda olan abonenin su tüketimi ile ilişkilendirilerek bulunacak ortalama üzerinden evsel katı atık ücretinin belirlenmesinin daha rasyonel olacağı (Zengin ve Ulutaş, 2016: 38), ayrıca bu yöndeki bir hesaplamanın kirleten öder ilkesine daha uygun yöntem olacağı öngörülmektedir.

\subsection{Faturalandirma}

Yönetmelik uyarınca evsel katı atık hizmetlerine ait ücretlendirmenin söz konusu hizmetin karşılığında düzenli aralıklarla su faturaları üzerinden yapılacağı belirtilmiştir. Anılan düzenleme büyükşehir belediyeleri dışındaki belediyeler açısından herhangi bir olumsuzluk içermemektedir. Başka bir deyişle bu belediyelerde evsel katı atık idaresi olan belediye aynı zamanda su abonesi sözleşmelerini de imzalamakta, su faturalarını tahsil etmekte, dolayısıyla da evsel aktı atık ücretini de su faturasına ekleyerek doğrudan doğruya bu ücreti de tahsil edebilmektedir. Ancak büyükşehir belediyeleri ile bu yerlerdeki ilçe belediyeleri evsel katı atık ücretini tahsil edebilmek için belirlenen formatta evsel katı atık ücreti ve grubu SUKI'lere iletilmekte, bu ücret faturalarda abonelere yansitılmakta, tahsil edilenler bu idarelere gönderilmektedir. Bu noktada iki esaslı sorun ortaya çıkmaktadır.

Çevre Temizlik Vergisinin tahsil edicisi olan SUKI'ler bu bedeli tahsil ederek \% 80'ini ilgili belediyeye, \% 20'sini de münhasıran çöp imha tesislerinin kuruluş ve işletmelerinde kullanılmak üzere büyükşehir belediyesinin hesabına aktarmaktadır. Ancak yönetimler arası mali ilişkiler kapsamında bu noktada SUKI'ler alacaklı oldukları idarenin bu gelirinden alacağını mahsup ederek ilgili belediyeye göndermektedir. Evsel katı atık ücretinin tahsili sonrasında da bu bedel ilgili belediyeye gönderilmesi sürecinde söz konusu sebeplerle bir mahsuplaşmaya gidilmesi halinde evsel katı atık hizmeti için toplanan ücretin anılan amaçla kullanılması ilkesine aykırı işlem de tesis edilmesi de muhtemel gözükmektedir.

Diğer bir husus ise tahsil edilemeyen bir evsel katı atık ücretinin icra sürecini SUKİ'nin mi yoksa ilgili evsel katı atık idaresinin mi yürüteceği hususudur. Yapılan icra masrafları ile diğer ödemelerin ne şekilde karşılanacağı, tahsil edilemeyen ücretlerden kimin sorumlu olacağı ve eğer bu

Turkish Studies - Economics, Finance, Politics

Volume 14 Issue 3, 2019 
sürecin SUKI'lerce yürütülmesi halinde gereksinime bağlı personel artışının bu idareye yükleyeceği maliyetin ne şekilde karşılanacağı hususlarında da önemli tereddütler bulunmaktadır. Diğer taraftan 5018 sayılı Kanun uyarınca yetkisiz tahsil ve ödemeyi yasaklayıcı 72' nci maddenin de bu aşamada nazara alınması gerekmektedir.

Buna göre yukarıda zikredilen iki husus ve buna bağlı sakıncaların giderilmesini teminen evsel aktı atık ücretinin faturalandırma ve tahsili konusunun büyükşsehir belediyeleri de dikkate alınarak tekrar gözden geçirilmesi gerekmektedir.

\section{4. Çevre Temizlik Vergisi ve Evsel Katı Atık Ücretinin Tek Tipleştirilmesi}

1993 yılında 2464 sayılı Belediye Gelirleri Kanununa "Çevre temizlik vergisi" başlıklı mükerrer 44 üncü madde eklenmiş ve belediye sınırları ile mücavir alanlar içerisinde bulunan ve belediyelerin katı atık toplama ve kanalizasyon hizmetlerinden istifade eden konut, işyeri ve başkaca amaçlarla kullanılan binalar "çevre temizlik vergisi” ödemekle yükümlü kılınmışlardır (Şentürk, vd. 2015: 14). Ancak 2003 yılında 5035 sayılı Kanunun 41 inci maddesi ile söz konusu madde tekrar düzenlenmiş, sadece belediyelerin çevre temizlik hizmetlerinden yararlanan konut, iş yeri ve diğer şekillerde kullanılan binaların çevre temizlik vergisi ödeyeceği hüküm altına alınmıştır. Böylece "katı atık toplama ve kanalizasyon hizmeti" lafzı değiştirilerek "çevre temizlik hizmetleri”" üzerinden vergi alınmaya başlanılmıştır.

Ancak kanalizasyon hizmetlerinden yararlanma sebebiyle ÇTV'den arındırılan bu vergi bir ücret halini almış, atıksu ücreti şeklinde su tüketimine göre tahsil edilmeye devam edilmektedir. Hâlihazırda atıksu ücreti $0,30 \mathrm{TL} / \mathrm{m}^{3}$ iken azami de içme suyu metreküp bedelinin $\% 50$ 'sini aşamayacağı hüküm altına alınmıştır. Öte yandan katı atık toplama faaliyeti yerine çevre temizlik hizmetleri şeklinde bir kavram kullanılmıştır. Yine bu maddeye göre konutlara ait çevre temizlik vergisi, su tüketim miktarı esas alınmak suretiyle metreküp başına her yılın başında yerelde oluşan atık miktarları esas alınmaksızın Merkezi idare tarafından çıkarılan Belediye Gelirleri Kanunu Genel Tebliği ile güncellenmektedir. Su tüketim miktarı esas alınmak suretiyle hesaplanan ÇTV, su faturasında ayrıca gösterilerek tahakkuk ettirilmekte, su tüketim bedeli ile birlikte belediyelerce tahsil edilmektedir. Ancak büyükşehirlerde bu bedel, su tüketimi esas alınarak su ve kanalizasyon idarelerince tahsil edilmektedir. Tahsil edilen bu bedelin \% 80'i gerekli toplama, taşıma ve temizlik görevini yapan ilçe belediyelerine aktarılırken kalan kısım da çöp imha tesislerinin kuruluş ve işletmelerinde kullanılmak üzere büyükşehir belediyesine aktarılmaktadır.

Su tüketimine bağlı olarak alınan ÇTV'nin bu haliyle evsel katı atıkları vergilemekten oldukça uzak olduğu, sadece sıvı atıkları vergileyebildiği, başka bir deyişle abonelerin ürettiği çöp miktarı dışında evlerin tükettiği su miktarına göre vergilemenin yapıldığg anlaşılmaktadır (Şentürk, vd. 2015: 15). Ancak hâlihazırda belediyelerce toplanan atık miktarı ile bu atığın taşınması ve bertaraf maliyetleri esas alındığında ÇTV mantığı ile su tüketimine bağlı "kirleten öder ilkesinin" bu maliyetleri karşılamaktan uzak olduğu açıktır. Bu noktada ÇTV ile Evsel Katı Atık Ücretinin dayanakları ve amaçları ile beraber ele alınarak, neredeyse aynı amaca hizmet eden bu vergi ve ücretlerin tek tipleştirilmesinde gerek yönetim süreçlerinin sadeleştirilmesi gerekse de vatandaşların kirlettiği kadar ödeme yapması noktasında kamusal bir yarar olduğu değerlendirilmektedir.

$\mathrm{Bu}$ noktada ÇTV ve Evsel Katı Atık Ücretinin mükerrer olmadığına da yer vermek gerekmektedir. Anılan ücretin hesaplanmasında yönetmelik gereği kullanılan Toplam Sistem Maliyeti, "yatırımın finansal maliyetini, sistemin işletilmesi ve bakımını, sabit varlıkların amortismanını, yönetim ve izleme giderlerini, vergileri, kamulaştırmayı ve sistemin finansal sürdürülebilirliğini sağlayacak öz kaynak getirisini de içeren toplam değer" şeklinde tanımlanırken aynı Yönetmeliğin 13 üncü maddesinde evsel katı atık ücretinin, 2464 sayılı Kanun uyarınca alınan ÇTV, kanalizasyon harcamalarına katılma payı ile kullanılmış suların uzaklaştırma bedellerinin toplam sistem maliyetinden çıkartılarak belirleneceğine yer verilmektedir. Böylece atık yönetimine dair yapılan 
giderin tamamından ÇTV geliri ile diğer gelirler düşüldükten sonra kalan kısmın evsel katı atık ücreti şeklinde kullanıcılara yüklendiği anlaşılmaktadır.

Görüleceği üzere sistemin özellikle ÇTV ve evsel katı atık ücreti özelinde tek tipleştirilmesi ve atık üreticisinin kirlettiği kadar ödemesini sağlayacak şekilde sistemin tasarlanması halinde yerelde yönetimsel bir kolaylık sağlanacağı, böylece kaynakların daha etkili, ekonomik ve verimli kullanılacağı değerlendirilmektedir. Başka bir deyişle birçok vergi ve ücretin çeşitli idareler veya birimlerce eşgüdümden yoksun süreçler izlenerek ve gereğinden fazla personel görevlendirilerek tahsili yoluna gidilmesi yerine bu vergi ve ücretlerin anlamsal bir birliktelik taşıyacak şekilde birleştirilmesi ve tek bir idare ve birim tarafindan idamesi mümkün olacak bir süreç izlenerek tahsil edilmesi bu aşamada daha rasyonel olacaktır. Diğer taraftan evsel katı atık ücreti ile ÇTV'nin büyükşehir belediyelerinde su ve kanalizasyon idareleri üzerinden su faturaları ile tahsili sürecinin de idareler arası mahsuplaşma sorunlarına yol açtığı ve açacağı da dikkate alınırsa, söz konusu vergi ve ücretlerin tek tipleştirilememesi halinde, her idarenin kendisine ait geliri kendisinin toplamasının daha yerinde olacağı değerlendirilmektedir. Bu çerçevede büyükşehir belediyelerinde ilçe belediyelerinin ÇTV ve evsel aktı atık ücretlerini emlak vergisi ile beraber tahsili yoluna gitmesinin idareler arası mali ilişkilerin sadeleşmesi açısından yararlı olacağı öngörülmektedir.

\section{Avrupa Birliğinde Evsel Katı Atık Yönetimi ve Vergilendirilmesi}

Küresel çevre sorunlarının artış göstermesi ile uluslararası hukukta çevresel düzenlemelerin önemi giderek artmıştır. Özellikle kaynakların kıtlığı ve uzun dönemde geri dönüşümü katı atık yönetiminde önemli önlemlerin alınmasını gerekli kılmıştır. Bu noktada Avrupa Birliği (AB), kaynakların verimli kullanımı ile eldeki kaynakların korunabilmesi noktasında çeşitli hukuki düzenlemeler yapma yoluna gitmiştir. Söz konusu çevresel mahiyetteki düzenlemeler Türkiye'ye göre oldukça eskiye dayanmaktadır. AB'de atık yönetimi konusunda 1975'ten başlamak üzere oldukça ayrıntılı direktifler yürürlüğe koyulmuş ve süreç içerisinde koşullara uygun hale getirilerek uygulama kabiliyeti artırılmıştır. Evsel katı atık hususunu da içeren bu direktiflerle beraber çevrenin korunması adına uzun vadeli hedefler belirlenmiştir. Bu çerçevede 2020 yılında inşaat atıklarının \% 70'i, evsel atıkların ise \% 50'sinin geri dönüştürülmesi amaçlanmıştır (Dönmez ve Değirmen, 2016: 253).

Atık yönetiminin AB'nin gündemine 1970'li yıllardan itibaren gelmeye başlamasıyla birlikte geri dönüşüm konusu hem ekonomik hem de çevresel açıdan önemini giderek artırmıştır. Özellikle çevre kirliliğinin ve kişi başı çöp miktarının artmasına bağlı olarak evsel katı atıkların geri dönüşümünün diğer atık türlerine nazaran daha kolay olması nedeniyle yeniden kazanımı gündeme gelmiş ve vergilendirilmesi gerekmiştir (Şentürk, Eser ve Polat, 2015: 5). Buna bağlı olarak da başlangıçta "Çevre Vergisi" adı altında tahsil edilen bu vergiler 1980'li yıllarda belirgin vaziyette uygulama alanı bulmuştur. Her ne kadar başlangıçta "kirleten öder" mantığı ile çevre vergileri ortaya çıksa da aslında gerçek hedef çevresel maliyetlerin içselleştirilmesi olmuştur (Reyhan, 2014: 113). Daha sonra bu amaç vergilendirme dâhilinde yine "kirleten öder" prensibi ile atık üretiminden caydırma halini almış, atıkların çıkış kaynağından itibaren vergilendirilmesi esas politika olarak kabul edilmiştir. Başka bir deyişle, atık üreten kişinin ekonomik olarak da sorumluluk altına girmesi amaçlanmıştır (Şentürk, Eser ve Polat, 2015: 6). Eurostat'a göre enerji, ulaştırma, kirlilik ve doğal kaynak olmak üzere AB'de dört çeşit vergilendirme uygulanmaktadır. Kirlilik vergileri; kirli su, evsel ve diğer katı atıklar gibi unsurlar üzerinden alınmaktadır (Reyhan, 2014: 114). AB'de çok az sayıda ülkede yerel yönetim düzeyinde kirlilik vergisi kullanılmakla birlikte, uygulamalar çöp ya da katı atık vergisi şeklinde yoğunluk göstermekte, çevresel anlamda yaygın vaziyette tek bir vergi türü kullanılmaktadır (Biyan ve Gök, 2014: 291).

Evsel katı atıkların vergilendirilmesinde, AB ülkelerindeki uygulamalarda önemli farkl11ıkların olduğu görülmektedir. Örneğin Avusturya'da çevre vergileri; enerji vergileri, nakliye vergileri, kirlilik vergileri ve kaynak vergilerinden oluşmaktadır. Ayrıca "bağlı hesap" adı verdikleri harç uygulamasına benzer bir uygulamaları da bulunmaktadır. Söz konusu harçlar atık su bedelleri,

Turkish Studies - Economics, Finance, Politics

Volume 14 Issue 3, 2019 
evsel olan ve olmayan katı atık toplama ücretleridir. Alınan bu ücretler toplanılış amacına uygun olarak kullanılmaktadır (Biyan ve Gök, 2014: 295). Almanya'da ise katı atık yönetimindeki vergilendirme "herkesin kendi atığı kadar ödemesi" ilkesine dayanmaktadır. Her ne kadar evsel katı atıkların toplanması ve bertaraf edilmesi noktasında vergilendirme politikası ve yöntemi her eyalette farklılık gösterse de alınacak ücret seviyesi ve bölgesel atık bertaraf kapasitesi hizmet sunulan alanın nüfus durumuna göre belirlenmektedir (Şentürk, Eser ve Polat, 2015: 10). Danimarka ise AB ülkeleri içinde en fazla çevre vergisi uygulayan ülkelerden biridir. Vergilerini genellikle çevre vergileri, kirlilik yayan kurumlara yönelik vergiler, su ve kıt olarak bulunan hammaddelere yönelik alınan vergiler olarak su tüketimi üzerinden almaktadır (Biyan ve Gök, 2014: 296). Ayrıca Danimarka 1993 yılında çevre vergisi konusunda reforma gitmiş ve bu reformla musluk suyu vergisi, atık su vergisi, plastik ve kâğıt bardak vergisi almaya başlamıştır (Çelikkaya, 2011: 110). AB ülkeleri arasında en düşük oranla çevre vergisi alan ülke ise Belçika'dır. Bu ülkede çevre vergileri; enerji, ulaşım ve kirlilik olarak alınmakta, kirlilik vergisi de gübre vergisi, çöp toplama ve yakma vergisi, su arıtma vergisi, su kirlilik vergisi, atık su vergisi gibi federe yönetimler tarafından toplanan vergilerden oluşmaktadır (Egeli ve Kerimoğlu, 2016: 445). İspanya'nın Barselona şehri ise çöp vergisini su faturası üzerinden almakta ve vergi alınan vatandaşların ödeyeceği ücret hem evdeki su tüketimine hem de bulundukları yerel bölgedeki çöp miktarına bağlı olarak saptanmaktadır (Şentürk, Eser ve Polat, 2015: 12). İsveç’te ise bazı yerel otoritelerce evsel katı atıkların çöp torbası başına veya evsel katı atığın ağırlığına göre vergilendirilmesi yoluna gidilmektedir. Bu uygulama akabinde evsel katı atık üretiminin söz konusu yerlerde önemli düzeyde azaldığı da tespit edilmiştir (Can, 2016: 66).

Avusturya ise tıpkı Belçika gibi atık su vergilerini, su tüketim miktarı üzerinden toplarken Yunanistan ve bir Doğu Avrupa ülkesi olan Çek Cumhuriyeti (Çekya) ise atık su miktarı üzerinden vergilendirme yapmaktadır. Norveç, sadece hane halkından alınan düz oranlı bir vergi sistemi uygulamaktadır. Polonya ve ABD'de hem su tüketiminden hem de geniş ölçekte su kirleticilerinden ayrı bir vergi alınmaktadır. İsveç'te ise atık su ve içme suyunu ayrı ayrı vergilendiren bir uygulama mevcuttur (Can, 2013: 153). Söz konusu ülkelerde de çöp veya evsel katı atık vergileri genel olarak su tüketimi üzerinden, kısmen de atık miktarı baz alınarak hesaplanması yoluna gidilmektedir.

Genel olarak AB ülkelerine bakıldığında Kirlilik Vergilerinin; Depolama Vergileri, Çöp Vergileri, Pil ve Akümülatör Vergileri ve Ambalaj Vergileri şeklinde sınıflandırıldığı, Depolama ve Çöp vergileri kapsamında evsel katı atıkların farklı yerel birimlerce farklı mahiyette ücrete tabi tutulduğu, başlangıçta birçok ülkede evsel katı atıklar da dâhil olmak üzere bu atıkların toplama hizmetleri için çöp miktarına bakılmaksızın değişmeyen sabit aylık ücretlerin alındığı (Can, 2016: 6566), bu uygulamanın da kirliliği önlemediği ve azaltmadığı, buna istinaden de kirleten öder ilkesi gereği tüketim miktarının esas alınmaya başlandığı, nihayetinde ise bütüncül ve sade vergileme uygulamalarına geçilerek bu konuda tek bir yerel otoritenin yetkili kılındığı, genel olarak bütün yerel birimler özelinde evsel katı atık uygulamalarının farklılaştığı, ancak temelde esas uygulamaların yukarıda zikredilen ortak amaçlara dayandığı değerlendirilmektedir.

Görüleceği üzere $A B$ ve gelişmiş ülkelerde evsel katı atık hususunun özel bir vergi veya genel bir vergi içerisinde alınan bir kalem şeklinde çeşitli yöntemlerle tahsil edildiği, eşgüdüm dâhilinde bir uygulama birliğinin olmadığ 1 görülmektedir. Başka bir deyişle her ülkenin veya eyaletin sahip olduğu kıt kaynaklar, evsel katı atık miktarı, kişi başı çöp miktarı, evsel katı atıkların toplanması, bertaraf edilmesi gibi hususlar nazara alınarak su tüketimi ve/veya atık miktarı üzerinden bir hesaplamaya gidildiği, bu noktada asıl belirleyici olan hususun ülkenin veya eyaletin iç dinamiklerinin olduğu, kirleten öder ilkesine istinaden sade bir vergilendirilme politikasının izlendiği ve temel amacın kirliliğin ve tüketimin azaltılması noktasında vergileme yoluyla caydırıcılık çerçevesinde yoğunlaştığı anlaşılmaktadır. 


\section{Sonuç ve Genel Değerlendirme}

Dünya'da özellikle gelişmiş ve gelişmekte olan ülkelerin yaşadıkları sanayileşme ve kentleşme süreci ile beraber her ne kadar yaşam standartları iyileşerek üretim süreçleri çeşitlense de bu gelişimin çevre üzerinde telafisi güç zararları belirmiş, çevre kirliliği ile beraber doğal kaynakların tüketilmesi süreci de son derece hızlanmıştır. Yaşanan bu gelişim her ne kadar insanların yaşam refahını artırsa da diğer taraftan onların sağlıklı ve dengeli bir çevrede yaşamasını olanaksız hale getirmiş, buna istinaden de özellikle gelişmiş ülkelerde çevrenin korunması adına düzenlemelere gidilmesi gerekmiştir. 1970'lerle beraber artan bu girişim ve duyarlılık Türkiye'de 1982 Anayasasının 56' ncı maddesinde karşılık bulmuş, herkesin sağlıklı ve dengeli bir çevrede yaşamasının yanı sıra çevreyi geliştirmek, çevre sağlığını korumak ve çevre kirlenmesini önlemek Devletin ve vatandaşların ödevi haline getirilmiştir. 1983 yılında çıkarılan Çevre Kanunu ile önemli düzenlemelere yer verilmiş, özellikle evsel katı atıkların toplanması ve bertarafı görevi belediyelere verilmiş, maliyetin de bu hizmetlerden faydalananlarca karşılanması esası belirlenmiştir. Böylece atık tüketiminin azaltılması ile çevrenin korunması kirleten öder ilkesi ile desteklenmiştir. 5216 ve 5393 sayılı Kanunlarla da büyükşehir ve diğer belediyeler özelinde çevrenin korunması ve katı atıkların toplanması ile bertarafı özel kanunlarda da yer edinmiştir. 2010 yılında evsel katı atık tüketiminin azaltılması, geri dönüşümü ve çevrenin korunması adına bir yönetmelik çıkarılmış, bir yıl içerisinde de evsel katı atık idarelerinin bu yönetmeliğe uyum sağlaması zorunlu k1lınmıştır. Ancak 2011 yılından 2020 yılı sonuna dek altı farklı düzeltici yönetmelikle anılan uyum sağlama süreci hep ötelenmiş, böylece evsel katı atık yönetim sisteminin işlerlik kazanması engellenerek bu geçiş sürecinin uzatılmasının ilgili idarelerce kanıksanmasına yol açılmıştır.

Hâlihazırda çok az idarece uygulanan yönetmelik incelendiğinde 2010 yılındaki bu düzenlemenin özellikle büyükşehir belediyeleri kapsamındaki idareler arasındaki sorunları çözecek bir mahiyet taşımadığı, esaslı noktalarda hüküm içermediği gibi maliyet hesaplama noktasında oldukça ayrıntılı olduğu, yapısal ve yönetsel sorunlar sebebiyle belediyelerce uygulanmasının da güç olduğu görülmüştür.

$\mathrm{Bu}$ noktada evsel katı atık yönetim sisteminin sorunsuz bir şekilde hayata geçirilebilmesi ve idame ettirilebilmesi için öncelikle ilgili yönetmeliğin ayrıntıll bir şekilde düzenlenmesi ve uygulamada karşılaşılan sorunları giderecek mahiyette çözümler sunması gerekmektedir. $\mathrm{Bu}$ kapsamda öncelikle yönetmelik kapsamında evsel katı atık toplama ve bertaraf sisteminin çevrenin korunması bilinci ile hizmet edeceği amaçların ve özellikle de evsel katı atık tanımı ile bu atıkların mahiyetinin açık bir şekilde tanımlanmasında yarar görülmektedir. Bunun yanı sıra maliyetin hesaplanması gibi süreçlerin sadeleştirilmesi ve bu sürecin belediyelerin personel yapısı da dikkate alınarak uygulanabilecek şekilde tasarlanması sistemin işleyişine fayda sağlayacaktır. Evsel katı atık idarelerinin aboneleri ile yapması zorunlu kılınan sözleşmenin yerine su aboneliği sözleşmesinin bir yargı kararı gereğince kabul edileceği yönünde karar bulunmakta olup, bu içtihat ile özellikle büyükşehir belediyelerinde yer alan idareler özelinde anılan belirsizliğin kaldırılmasını sağlayacak bir düzenlemeye gidilmesi gerekmektedir. Bu noktada evsel katı atık abone sözleşmesi ve/veya içme ve kullanma suyu aboneliğine dair bir tip sözleşmenin veya bu sözleşmeye eklenecek bir maddenin belirlenmesi eşgüdümü sağlayacaktır.

Evsel katı atık ücretinin belirlenmesine gelince atık miktarının tespiti ile beraber aboneler özelinde yeterince ölçülebilir bir mahiyet taşımayan hane halkı, öğrenci ve hasta sayısı gibi sürekli değişebilen verilerin esas alınarak hazırlanacak değişken tarifeye veya atık üreticilerinin etkileyemeyeceği sabit tarifeye göre ücretin belirleneceği düzenlenmiştir. Oysa kirleten öder ilkesi gereği aynı maddede her atık üreticisinin aldığ 1 hizmetlerin maliyetinin dikkate alınması ve herkesin kirlettiği kadar evsel katı atık ücreti ödemesi gerektiği belirtilmektedir. Dolayısıyla hâlihazırdaki mevzuata göre kirletenin bu tarifelere göre kirlettiği miktar ile buna mukabil ücretin tespiti nesnel bir şekilde bulunamayacaktır. Bu noktada toplam sistem maliyeti kapsamında bulunan abone başı sabit

Turkish Studies - Economics, Finance, Politics

Volume 14 Issue 3, 2019 
ücretin su tüketimi ile ilişkilendirilerek evsel katı atık ücretinin belirlenmesi yönündeki bir uygulamanın var olan tarifeye göre daha rasyonel olacağı değerlendirilmektedir.

Mer'i mevzuat uyarınca evsel katı atıkları toplama ve taşıma aşamalarının da dâhil olduğu katı atıkların bertaraf sürecine ilişkin giderlerin, buna bağlı olarak tarifelerin ve ücretin belirleme nihai yetkisinin büyükşsehir belediye meclisinde olmasına rağmen bazı büyükşehir ilçe belediyelerinin taşıma ve toplama giderleri üzerinden özerk bir şekilde evsel katı atık ücretini belirlediği, ancak anılan idari işlemlerin idari yargı kararları ile iptal edildiği de görülmüştür. Büyükşehir belediyelerinin bu asli görevi kapsamında eşgüdümü de sağlamak adına ilçe belediyelerince farklı maliyet kalemleri ile taşıma ve toplama giderlerinin hesaplanmasını önleyerek ortak maliyet kalemlerinin esas alınmasını sağlayarak ilçe belediyeleri ile beraber bu süreci nihayete erdirmesinin daha rasyonel olacağ değerlendirilmektedir.

Diğer taraftan evsel katı atık ücretinin su faturaları üzerinden faturalandırılması uygulamasında büyükşehir belediyeleri kapsamında iki önemli sorunun yaşanması muhtemel gözükmektedir. Evsel katı atık toplama ücretinin ilçe belediyeleri tarafindan SUKI'lere, bertaraf ücretinin de yine aynı şekilde büyükşehir belediyelerince SUKI'lere bildirilmesi sonrasında yapılan tahsilatın bu iki idareye tanzim edilerek gönderilmesi ve tahsil edilemeyenlerin de icraya konulması sürecinde mevzuat kapsamında önemli belirsizlikler bulunmaktadır. Bu noktada tahsil edilen ücretin SUKI'ler tarafından ilgili belediyeden alacakları karşılı̆̆ında mahsup edilmesi halinde bu gelirin belediyelerce amaç kapsamında kullanılması ilkesi ihlal edilecektir. Ayrıca tahsil edilemeyen alacakların ise icra sürecine hangi idare tarafından konulacağı da belirsizlik taşımaktadır. $\mathrm{Bu}$ sakıncalarla beraber yönetmeliğin faturalandırma maddesinin büyükşehir belediyeleri ile tahsilatların yetkisiz bir idare tarafindan yapılmaması gerektiğini düzenleyen 5018 sayılı Kanunun 72 nci maddesi de esas alınarak düzenlenmesi gerekmektedir.

Bu çerçevede, Avrupa Birliği’nde ve diğer gelişmiş ülkelerde olduğu gibi kirleten öder ilkesinin esas alınarak bütüncül mahiyette sade bir vergileme uygulaması ile hareket edilmesi, özellikle evsel katı atıkla beraber diğer kirlilik unsurlarını da kapsayıcı vergilerin muhatabının tek bir idare haline getirilmesinde yarar görülmektedir. Dolayısıyla Türkiye'de ÇTV ve evsel katı atık ücreti özelinde bir tek tipleşmeye gidilmesi ve atık üreticisinin kirlettiği kadar ödemesini sağlayacak şekilde bir sistemin tasarlanması da yönetimsel bir kolaylık sağlayacak, dolayısıyla kaynakların daha etkili, ekonomik ve verimli bir şekilde kullanılacağı öngörülmektedir. Böylece çeşitli vergi ve ücretlerin farklı oluşumlarca ve sayıca fazla personel eliyle tahsili yerine tek bir vergi veya ücret halinde tek bir birim ve sınırlı sayıda personelce tahakkuk ve tahsil sürecinin yürütülmesinde kamu yararı olacağı değerlendirilmektedir. Ancak bu tek tipleşmenin sağlanamaması halinde ise büyükşehirler özelinde ilçe belediyelerinin ÇTV ve evsel aktı atık ücretlerini emlak vergisi ile beraber tahsili yoluna gitmesinin idareler arası mali ilişkilerin sadeleşmesi açısından yararlı olacağı öngörülmektedir.

$\mathrm{Bu}$ yönde yapılacak düzenlemelerin gerek kent gerekse de ülke düzeyinde çevrenin korunması noktasında önemli faydalar sağlayacağı, diğer taraftan belediyelerin içerisinde bulunduğu yapısal ve yönetsel sorunları da asgariye indirgeyeceği açıktır. Ayrıca evsel katı atık sisteminin uygulanması ile süreç içerisine öncelikle geri dönüşümlerin artması, öte yandan da kirleten öder ilkesi ile atık miktarının giderek azalması sağlanacak, böylece geçmişe nazaran atık miktarının azalması ile çevre duyarlılığı daha da artmış olacaktır.

\section{KAYNAKÇA}

29/05/1981 tarih ve 17354 sayılı Resmi Gazete'de yayımlanan 2464 sayılı Belediye Gelirleri Kanunu. 11/08/1983 tarih ve 18132 sayılı Resmi Gazete'de yayımlanan 2872 sayılı Çevre Kanunu.

14/03/1991 tarihli ve 20814 sayılı Resmi Gazete'de yayımlanan Katı Atıkların Kontrolü Yönetmeliği.

Turkish Studies - Economics, Finance, Politics

Volume 14 Issue 3, 2019 
23/7/2004 tarih ve 25531 sayı1ı Resmi Gazetede yayımlanan Büyükşehir Belediyesi Kanunu.

14/03/2005 tarihli ve 25755 sayılı Resmi Gazete'de yayımlanan Tehlikeli Atıkların Kontrolü Yönetmeliği.

13/7/2005 tarih ve 25874 sayılı Resmi Gazetede yayımlanan Belediye Kanunu.

05/07/2008 tarihli ve 26927 sayılı Resmi Gazete'de yayımlanan Atık Yönetimi Genel Esaslarına İlişkin Yönetmelik.

27/10/2010 tarihli ve 27742 sayılı Resmi Gazete'de yayımlanan Atıksu Altyapı Ve Evsel Katı Atık Bertaraf Tesisleri Tarifelerinin Belirlenmesinde Uyulacak Usul Ve Esaslara İlişkin Yönetmelik.

02/04/2015 tarih ve 29314 sayılı Resmi Gazete'de yayımlanan Atık Yönetimi Yönetmeliği.

10/07/2018 tarih ve 30474 sayılı Resmi Gazete'de yayımlanan 1 Nolu Cumhurbaşkanı Kararnamesi.

Atık Yönetimi Hakkında AB Müktesebat Rehberi, Türkiye Metal Sanayicileri Sendikası (MESS) tarafindan CPS'ye hazırlatılan rapor, 2012, s. 1-97.

Biyan, Ö. ve Gök M. (2014). "Çevre Politikaları Kapsamında Avrupa Birliği ve Türkiye'de Çevre Vergilerini Uygulanışı: Karşılaştırmalı Bir Analiz”, Hitit Üniversitesi Sosyal Bilimler Enstitüsü Dergisi, Yıl 7, Say1 2, s. 281-310.

Can, F. (2016). “Çevre Politikasının Ekonomik Araçları”, Niğde Üniversitesi İktisadi ve İdari Bilimler Fakültesi Dergisi, Cilt 9, Sayı 1, s. 58-73.

Can, F. (2013). "Çevre Sorunlarının Çözümüne Yönelik Bir Araç Olarak Çevre Vergisi Uygulamaları”, Vergi Sorunları Dergisi, Say1 292, s. 146-156. http://idealonline.com.tr/IdealOnline/lookAtPublications/paperDetail.xhtml?uId=13960 (Erişim Tarihi: 06.06.2019).

Çelikkaya, A. (2011). "AB Üyesi Ülkelerde Çevre Vergisi Reformları ve Türkiye'deki Durumun Değerlendirilmesi”, Anadolu Üniversitesi Sosyal Bilimler Dergisi, Cilt 11, Say1 2, s. 97-120.

Çevre ve Şehircilik Bakanlığı Çevre Yönetimi Genel Müdürlüğü (2012). Tehlikeli Atıkların Sinıflandırılması Kılavuzu, Cilt 1, s. 1-112.

Çevre Yönetimi Genel Müdürlüğü (2011). "Evsel Katı Atık Tarifelerinin Belirlenmesine Yönelik Kilavuz",

http://www.cygm.gov.tr/CYGM/Files/yayinlar/kilavuz/Evsel\%20Kat\%C4\%B1\%20At\%C4\% B1k\%20Tarifelerinin\%20Belirlenmesine\%20Y\%C3\%B6nelik\%20K\%C4\%B1lavuz\%20ve\%2 0Ekleri.pdf, (Erişim Tarihi: 26/12/2018).

Dönmez, E. ve Değirmen N. (2016). "Avrupa Birliği (AB) ve Türkiye'deki Atık Yönetimi Uygulamalarının Karşılaştırılması", International Symposium on Environment andMorality, Alanya, s. 249-258.

Egeli, H. (2016). "Uluslararası Vergi Sorunları Bağlamında Belçika Vergi Sisteminin Değerlendirilmesi”, Celal Bayar Üniversitesi İ.I..B.F. Yönetim ve Ekonomi Dergisi, Cilt:23,Say1:2, s. 435-450.

EUROSTAT, ProductsEurostat News https://ec.europa.eu/eurostat/web/products-eurostat-news//DDN-20180123-1, (Erişim Tarihi: 23.01.2018).

Gündüzalp, A. A. ve Güven, S. (2016). “Atık, Çeşitleri, Atık Yönetimi, Geri Dönüşüm ve Tüketici: Çankaya Belediyesi ve Semt Tüketicileri Örneği”, Hacettepe Üniversitesi Sosyolojik 
Araştırmalar E-Dergisi, s. 1-19, http://www.sdergi.hacettepe.edu.tr/makaleler/Atik-CesitleriYonetimi-GeriDonusumVeTuke tici.pdf, (Erişim Tarihi 26/12/2018).

Kemirtlek, A.. "Entegre Kat1 Atı http://istac.com.tr/contents/44/cevremakaleleri_130838592910380265.pdf, (Erişim Tarihi: 28/05/2019).

Reyhan, S. A. (2014). "Çevre Vergisinde Çevre Vergileri Uygulamaları”, Hitit Üniversitesi Sosyal Bilimler Enstitüsü Dergisi, Y1l 7, Sayı 1, s. 110-120.

Saltabaş, F., Soysal, Y., Ş. Yıldız ve Balahorli, V. (2011). "Evsel Katı Atık Termal Bertaraf Yöntemleri ve İstanbul'a Uygulanabilirliği”, SigmaJournal of Engineeringand Natural Sciences, Volume: 3, Issue: 1, pp:109-116.

Sayıştay Başkanlığı, Balıkesir Su ve Kanalizasyon İdaresi Genel Müdürlüğü 2017 Yılı Denetim Raporu, https://www.sayistay.gov.tr/tr/Upload/62643830/files/raporlar/kid/2017/Belediyeler/BALIKE S\%C4\%B0R\%20BASK\%C4\%B0.pdf, (Erişim Tarihi: 17/01/2019).

Şentürk, S. H., Eser, L. Y. ve Polat, S. (2015). "Evsel Katı Atıkların Vergilendirilmesi: Türkiye'de Çevre Temizlik Vergisine Fayda İlkesi Çerçevesinde Eleştirel Bir Bakış", Maliye Dergisi, Say1 169, s. 1-20.

Taşer, A. ve Erdoğan B. Z. (2010). “Avrupa Birliği ve Türkiye'de Tehlikeli Atık Yönetiminin Yasal Gelişimi”, Eskişehir Osmangazi Üniversitesi İIBBF Dergisi, Ekim 2010, 5(2), s. 67- 84.

TÜİK, Belediye Atık İstatistikleri, Sayı: 24876, 29 Kasım 2017.

Y1lmaz, A. ve Bozkurt, Y. (2010). "Türkiye'de Kentsel Katı Atık Yönetimi Uygulamaları Ve Kütahya Katı Atık Birliği (KÜKAB) Örneği”, Süleyman Demirel Üniversitesi İktisadi ve İdari Bilimler Fakültesi Dergisi, Cilt:15, Say1: 1, s.11-28.

Zengin, E. ve Ulutaş, K. (2016). "Büyükşsehir İlçe Belediyelerinde Evsel Katı Atık Ücret Tarifelerinin Belirlenmesi ve Uygulanması", Yalova Sosyal Bilimler Dergisi, Y1l 6, Sayı 11, s. 26-42. 